\title{
Identification of Novel Bacterial Members of the Imine Reductase Enzyme Family that Perform Reductive Amination
}

DOI:

$10.1002 /$ cctc. 201701408

\section{Document Version}

Accepted author manuscript

Link to publication record in Manchester Research Explorer

\section{Citation for published version (APA):}

France, S., Weise, N., Mangas-Sanchez, J., Montgomery, S., Howard, R. M., \& Turner, N. (2018). Identification of Novel Bacterial Members of the Imine Reductase Enzyme Family that Perform Reductive Amination.

ChemCatChem. https://doi.org/10.1002/cctc.201701408

\section{Published in:}

\section{ChemCatChem}

\section{Citing this paper}

Please note that where the full-text provided on Manchester Research Explorer is the Author Accepted Manuscript or Proof version this may differ from the final Published version. If citing, it is advised that you check and use the publisher's definitive version.

\section{General rights}

Copyright and moral rights for the publications made accessible in the Research Explorer are retained by the authors and/or other copyright owners and it is a condition of accessing publications that users recognise and abide by the legal requirements associated with these rights.

\section{Takedown policy}

If you believe that this document breaches copyright please refer to the University of Manchester's Takedown Procedures [http://man.ac.uk/04Y6Bo] or contact uml.scholarlycommunications@manchester.ac.uk providing relevant details, so we can investigate your claim.

\section{OPEN ACCESS}


Heterogeneous \& Homogeneous \& Bio- \& NanoCHEMCATCHEM CATALYSIS

\section{Accepted Article}

Title: Identification of Novel Bacterial Members of the Imine Reductase Enzyme Family that Perform Reductive Amination

Authors: Scott P France, Roger M Howard, Jeremy Steflik, Nicholas J Weise, Juan Mangas-Sanchez, Sarah L Montgomery, Robert Crook, Rajesh Kumar, and Nicholas John Turner

This manuscript has been accepted after peer review and appears as an Accepted Article online prior to editing, proofing, and formal publication of the final Version of Record (VoR). This work is currently citable by using the Digital Object Identifier (DOI) given below. The VoR will be published online in Early View as soon as possible and may be different to this Accepted Article as a result of editing. Readers should obtain the VoR from the journal website shown below when it is published to ensure accuracy of information. The authors are responsible for the content of this Accepted Article.

To be cited as: ChemCatChem 10.1002/cctc.201701408

Link to VoR: http://dx.doi.org/10.1002/cctc.201701408 


\title{
Identification of Novel Bacterial Members of the Imine Reductase Enzyme Family that Perform Reductive Amination
}

\author{
Scott P. France, ${ }^{[a]}$ Roger M. Howard,${ }^{[b, c]}$ Jeremy Steflik,${ }^{[b]}$ Nicholas J. Weise, ${ }^{[a]}$ Juan Mangas- \\ Sanchez, ${ }^{[\mathrm{a}]}$ Sarah L. Montgomery, ${ }^{[\mathrm{a}]}$ Robert Crook, ${ }^{[\mathrm{c}]}$ Rajesh Kumar ${ }^{*[\mathrm{~b}]}$ and Nicholas J. Turner ${ }^{*[\mathrm{a}]}$
}

\begin{abstract}
Reductive amination of carbonyl compounds constitutes one of the most efficient ways to rapidly construct chiral and achiral amine frameworks. Imine reductase (IRED) biocatalysts represent a versatile family of enzymes for amine synthesis via NADPH mediated imine reduction. The reductive aminases (RedAms) are a sub-family of IREDs which have recently been shown to catalyse imine formation as well as imine reduction. Herein, a diverse library of novel enzymes were expressed and screened as cell-free lysates for their ability to facilitate reductive amination, in order to expand the known suite of biocatalysts for this transformation and to identify more enzymes with potential industrial applications. A range of ketones and amines were examined and enzymes were identified that were capable of accepting benzylamine, pyrrolidine, ammonia and aniline. Amine equivalents as low as 2.5 were employed to afford up to $>99 \%$ conversion and for chiral products, up to $>98 \%$ e.e. could be achieved. Preparative-scale reactions were conducted with low amine equivalents (1.5 or 2.0 ) of methylamine, allylamine and pyrrolidine, achieving up to $>99 \%$ conversion and $76 \%$ isolated yield.
\end{abstract}

Secondary and tertiary amines are motifs present in many natural products, active pharmaceutical ingredients (APIs) and agrochemicals. Unsurprisingly, the synthesis of these frameworks has been the focus of considerable research efforts. One of the most powerful ways to construct these architectures is via reductive amination of a carbonyl compound with an amine because it can enable the coupling of two smaller fragments directly with concomitant formation of a stereogenic centre. A number of advances have recently been made in the field of catalytic asymmetric reductive amination processe ${ }^{[1-5]}$ although there are still considerable challenges such as the chemoselectivity of the catalyst for imine functionality, the disfavoured equilibrium of imine formation in water and the enantioselectivity of the reaction. ${ }^{[6]}$ Alternatively, preformation of the imine followed by asymmetric transition metal-catalysed hydrogenation is an option, ${ }^{[7-12]}$ although it is a two-step process and brings with it additional safety considerations around the use of hydrogen. Furthermore, achiral secondary and tertiary amine motifs are also present in many bioactive compounds and their synthesis by reductive amination is often advantageous over $\mathrm{N}$-alkylation which requires toxic alkylating agents and can easily lead to over-addition products.

[a] Mr S. P. France, Dr. N. J. Weise, Dr. J. Mangas-Sanchez, Miss S. L. Montgomery, Prof. N. J. Turner

School of Chemistry, University of Manchester, Manchester Institute of Biotechnology, 131 Princess Street, Manchester M1 7DN, UK.

E-mail: nicholas.turner@manchester.ac.uk

[b] Dr. R. M. Howard, Mr. J. Steflik, Dr. R. Kumar

Groton Laboratories, Pfizer Worldwide Research and Development, 445 Eastern Point Road, Groton, Connecticut, 06340, US. E-mail:Rajesh.Kumar3@pfizer.com

[c] Dr. R. M. Howard, Mr. R. Crook

Sandwich Laboratories, Pfizer Worldwide Research and

Development, Discovery Park, Sandwich, Kent, CT13 9NJ, UK.
As an alternative to traditional chemical methods, biocatalysis is becoming an increasingly desirable option for industry due to the benefits of sustainable catalyst supply, milder reaction conditions and the enantioselectivity offered by enzymes. One of the more recent additions to the suite of biocatalysts available for chiral amine synthesis are imine reductases (IREDs) that catalyse the asymmetric reduction of prochiral imines using the cofactor NADPH (Figure 1a). ${ }^{[13-16]}$ It has also been shown that, in addition to reduction of preformed imines, certain enzymes of this class can also enable reductive amination between a carbonyl and amine substrate. ${ }^{[17-22]}$ Furthermore, we have recently identified enzymes from a sub-group of the IRED enzyme family that catalyse imine formation as well as imine reduction. These reductive aminases (RedAms) from fungi are able to utilise stoichiometric or near-stoichiometric ketone:amine equivalents to achieve high conversions (Figure 1b). ${ }^{[23]}$ Other enzyme classes that catalyse reductive amination include amino acid dehydrogenases (AADHs) and the engineered amine dehydrogenases $(\mathrm{AmDHs})^{[24,25]}$ as well as $\mathrm{N}$-methyl-amino acid dehydrogenases (NMAADHs), ${ }^{[26]}$ although, to date, the latter are limited to ammonia or methylamine as the amine coupling partner. ${ }^{[27]}$ Opine dehydrogenases $(\mathrm{OpDHs})$ catalyse reductive amination between an amino acid and keto acid and have been engineered to broaden their substrate scope and application by Codexis. ${ }^{[28]}$

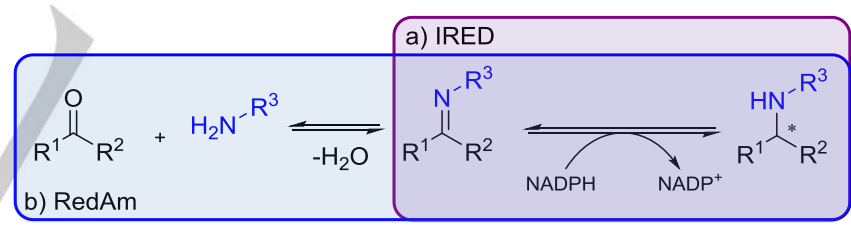

Figure 1: Imine reductase (IRED) and reductive aminase (RedAm) biocatalysts for amine synthesis. a) IRED-catalysed reduction of preformed imines. b) RedAm-catalysed imine formation and subsequent reduction.

In light of the recent identification of fungal RedAms, we decided to investigate new bacterial IREDs as biocatalysts for reductive amination with particular emphasis on operating at nearstoichiometric amounts of ketone and amine reagents.

A group of 45 bacterial IREDs was selected using the Basic Local Alignment Search Tool (BLAST) which included 27 novel enzymes and 18 enzymes previously disclosed ${ }^{[17,29-35]}$ (see Supporting Information). The protein sequences of the known IREDs from Pseudomonas putida (3L6D), ${ }^{[30]}$ Streptomyces sp. GF3546 (BAM99301) ${ }^{[33,34]}$ and an undisclosed IRED of industrial interest, all of which have broad substrate specificity, were used as query sequences. Genes were synthesised, subcloned into pET28b, expressed in E. coli BL21 (DE3) and applied as cellfree lysates (see Supporting Information). Preliminary screening with cell-free lysate containing the reductive aminase from Aspergillus oryzae (AspRedAm $)^{[23]}$ suggested successful reductive amination could be achieved by using a crude biocatalyst preparation (see Supporting Information). 
<smiles>CC1CCC(=O)CC1</smiles><smiles>CCCCC(C)=O</smiles><smiles>CC(=O)CCc1ccccc1</smiles><smiles>O=C1CCc2ccccc2C1</smiles><smiles>O=C1CCN(C(=O)O[Na])C1</smiles><smiles>O=C1CCN(C(=O)OCc2ccccc2)C1</smiles>

6

Amine Substrates<smiles>C=CCN</smiles><smiles>NCc1ccccc1</smiles>

$\mathrm{NH}_{3}$

f

Figure 2: Reductive amination ketone and amine substrate panel for IRED screening.

A panel of model ketones 1-8 and amines a-f was selected to study the reductive amination activity of the novel enzymes. The IRED library was first screened with the panel of ketones 1-8 and methylamine a. For the purposes of initial testing, 50 equivalents of amine a were used to maximise the chances of identifying hits. However, with ketone substrates 1 and 2 that have recently been demonstrated to work well with near stoichiometric quantities of amine coupling partner, ${ }^{[23]}$ reactions were conducted at 2.5 amine equivalents. The results of biotransformations with a selection of the best performing enzymes are presented in Table 1 (for full screening results see the Supporting Information).

Ketone 1 was accepted by the majority of enzymes in the library with modest to high conversions achieved. Interestingly, in the conversion of the prochiral ketones 2-4, a large proportion of the enzyme library afforded (S)-configured products. These examples constitute valuable additions to the toolbox of biocatalysts for reductive amination since they are enantiocomplementary to the previously described AspRedAm. The $\mathrm{N}$-protected pyrrolidinone substrates $\mathbf{5}$ and $\mathbf{6}$ were generally more challenging substrates. However, interestingly IR48 afforded high conversion with the Cbz-protected analogue 5. The products $5 \mathbf{a}$ and $\mathbf{6 a}$ are industrially relevant since the $\mathrm{N}$ methylpyrrolidin-3-amine framework is found in a number of biologically active compounds described in the academic and patent literature. ${ }^{[36-39]} \quad$ Substrates $\alpha$-tetralone $\mathbf{7}$ and acetophenone $\mathbf{8}$ showed little to no conversion across the entire library of enzymes screened.

To explore the substrate scope of reductive amination with respect to the amine substrate, cyclohexanone 1 was chosen as the model compound and screened against a panel of amines $\mathbf{b}$ f. This panel encompassed primary and secondary amines including ammonia $\mathbf{f}$ as well as bulkier amines and those with chemical handles for further synthesis. With larger and more expensive amine donors, it is clearly important that this component is added in a low number of equivalents relative to the ketone substrate to lower costs and reduce product contamination, thereby minimising downstream processing. However, when using ammonia $\mathbf{f}$, for example, the volatility of the amine necessitates a higher loading but it is also inexpensive and can be easily removed during work up. Therefore, for the library screening presented in Table 2, 2.5 equivalents of amines b-e were used while 20 equivalents were added in the case of ammonia $\mathbf{f}$.

Table 1: Biotransformation data for screening of a subset of the best performing enzymes for reductive amination of a panel of ketones 1-6 with methylamine a.

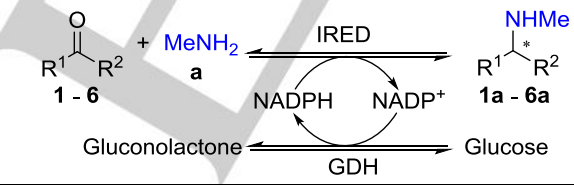

\begin{tabular}{|c|c|c|c|c|c|c|}
\hline \multirow[b]{2}{*}{ Enzyme } & \multicolumn{6}{|c|}{ Apparent conversion to product $/ \%$, e.e. $/ \%$ ( $R$ or $S$ ) } \\
\hline & 1a & $2 a$ & $3 a$ & $4 a$ & $* \mathrm{NHMe}$ & ${ }^{*} \mathrm{NHMe}$ \\
\hline IR44 & 94 & $45,>98(S)$ & $>99,>98(S)$ & $19,>98(S)$ & 0 & 25 \\
\hline IR46 & 95 & 6 & 6 & $53,>98(R)$ & 0 & 0 \\
\hline IR47 & 98 & $19,78(S)$ & $>99,26(R)$ & $41,18(S)$ & $58,89(S)$ & 14 \\
\hline IR48 & 96 & $41,>98(S)$ & $>99,>98(S)$ & $22,>98(S)$ & $89,96(S)$ & 38 \\
\hline $\operatorname{IR} 50$ & 98 & $46,>98(S)$ & $>99,>98(S)$ & $19,>98(S)$ & 23 & 4 \\
\hline IR51 & 95 & 4 & 1 & $44,>98(R)$ & 0 & 0 \\
\hline IR56 & 97 & $43,>98(S)$ & $>99,>98(S)$ & 12 & 0 & 4 \\
\hline IR58 & 98 & $7,53(R)$ & 2 & $51,>98(S)$ & 0 & 0 \\
\hline IR59 & 13 & $7,>98(S)$ & $56,>98(S)$ & 1 & 0 & 0 \\
\hline IR61 & 79 & $32,>98(S)$ & $99,>98(S)$ & 2 & 27 & 16 \\
\hline IR62 & 31 & 1 & 1 & $66,7(R)$ & 0 & 5 \\
\hline IR66 & 99 & $9,50(R)$ & $8,62(S)$ & $50,51(S)$ & 2 & 0 \\
\hline IR67 & 70 & 2 & 0 & $10,>98(S)$ & 0 & 0 \\
\hline IR68 & 19 & 3 & $43,>98(S)$ & 3 & 2 & 0 \\
\hline IR69 & 18 & 0 & 0 & $10,>98(S)$ & 0 & 0 \\
\hline IR70 & 97 & 5 & 1 & $10,>98(S)$ & 1 & 23 \\
\hline IR77 & 98 & $43,>98(S)$ & $>99,>98(S)$ & $18,>98(S)$ & 0 & 0 \\
\hline IR91 & 22 & 0 & $30,76(S)$ & $74,>98(S)$ & 22 & 85 \\
\hline
\end{tabular}

Reaction conditions: Ketone (1, 2: $10 \mathrm{mM}$; 3-6: $5 \mathrm{mM}$ ), methylamine a (for reactions with 1, 2: $25 \mathrm{mM}$; for 3-6: $250 \mathrm{mM}$ ), glucose (50 mM), GDH CDX-901 (0.3 $\mathrm{mg} / \mathrm{mL}), \mathrm{NADP}^{+}(0.4 \mathrm{mM})$, enzyme lysate in Tris buffer $(100 \mathrm{mM}, \mathrm{pH} 9.0)$. Incubated at $25^{\circ} \mathrm{C}, 250 \mathrm{rpm}$ for $24 \mathrm{~h}$. For full screening results, see the Supporting Information. Conversion determined by GC-FID and e.e. by chiral phase GC-FID or HPLC. 
Table 2: Biotransformation data for screening of a subset of the best performing enzymes for reductive amination of $\mathbf{1}$ with amines $\mathbf{b}-\mathbf{f}$.

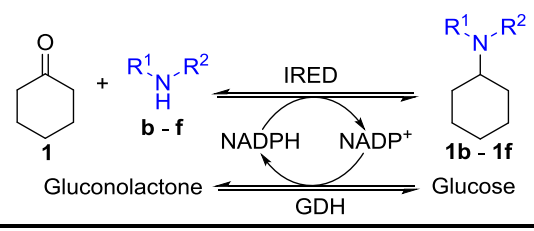

Apparent conversion to product/\%

\begin{tabular}{cccccc}
\hline Enzyme & $\mathbf{1 b}$ & $\mathbf{1 c}$ & $\mathbf{1 d}$ & $\mathbf{1 e}$ & $\mathbf{1 f}$ \\
\hline IR44 & 92 & 79 & 11 & 99 & 0 \\
IR46 & 11 & 1 & 0 & 15 & 0 \\
IR47 & 72 & 66 & 30 & 83 & 5 \\
IR48 & 83 & 79 & 9 & 91 & 0 \\
IR50 & 80 & 76 & 20 & 99 & 0 \\
IR51 & 15 & 4 & 0 & 13 & 0 \\
IR56 & 87 & 81 & 16 & 99 & 0 \\
IR58 & 74 & 1 & 0 & 78 & 10 \\
IR59 & 24 & 61 & 1 & 14 & 0 \\
IR61 & 65 & 78 & 10 & 83 & 0 \\
IR62 & 35 & 31 & 0 & 2 & 0 \\
IR66 & 84 & 2 & 1 & 79 & 20 \\
IR67 & 62 & 32 & 0 & 1 & 0 \\
IR68 & 10 & 23 & 5 & 7 & 0 \\
IR69 & 46 & 43 & 0 & 4 & 0 \\
IR70 & 78 & 1 & 0 & 55 & 2 \\
IR77 & 84 & 78 & 23 & 97 & 0 \\
IR91 & 30 & 63 & 1 & 8 & 0
\end{tabular}

Reaction conditions: 1 (10 mM), amine (b - e: $25 \mathrm{mM}$; f: $200 \mathrm{mM})$, glucose (50 $\mathrm{mM}), \mathrm{GDH}$ CDX-901 (0.3 mg/mL), NADP ${ }^{+}(0.4 \mathrm{mM})$, enzyme lysate in Tris buffer $(100 \mathrm{mM}, \mathrm{pH} 9.0)$. Incubated at $25^{\circ} \mathrm{C}, 250 \mathrm{rpm}$ for $24 \mathrm{~h}$. For full screening results, see the Supporting Information. Conversion determined by GC-FID.

Interestingly, the enzyme library performed well with allylamine b as well as the more bulky substrate benzylamine c. Furthermore, several enzymes were identified that gave high conversions with the secondary amine pyrrolidine e which must react via an iminium ion intermediate to afford the tertiary amine product $\mathbf{1 e}$. Interestingly, AspRedAm is unable to catalyse the formation of 1e, further highlighting the utility of the enzymes described herein. Aniline $\mathbf{d}$ was also a substrate for several of the biocatalysts. Due to the lower nucleophilicity of arylamine systems compared to simple alkylamines, enzymes that are capable of utilising $\mathbf{d}$ in reductive aminations with ketones are of particular interest with some recent advances in this area made independently by Roiban et al. ${ }^{[22]}$ during the course of our investigations. Ammonia $\mathbf{f}$ did not give high conversions, despite 20 equivalents being employed, although IR66 afforded $20 \%$ conversion to the product $\mathbf{1 f}$.

Preparative-scale reactions were performed with 1 with $100 \mathrm{mM}$ or $125 \mathrm{mM}$ substrate loading and 1.5 or 2 equivalents of amines $\mathbf{a}, \mathbf{b}$ and $\mathbf{e}$, achieving high conversions and good isolated yields. All these reactions showed good initial rates of reaction, resulting in $>60 \%$ conversion in the first $6 \mathrm{~h}$ before slowing down. These larger-scale reactions revealed that the use of the glucose/GDH cofactor recycling system resulted in a drop in reaction $\mathrm{pH}$, and therefore titration with $2 \mathrm{~N}$ sodium hydroxide solution was required to maintain a pH of 8 over the course of the reaction. To date, these represent the highest substrate loadings for preparative reductive aminations with IREDs described in the literature. Intensification efforts for the synthesis of $(S)-5$ a were limited by the solubility of substrate 5 .

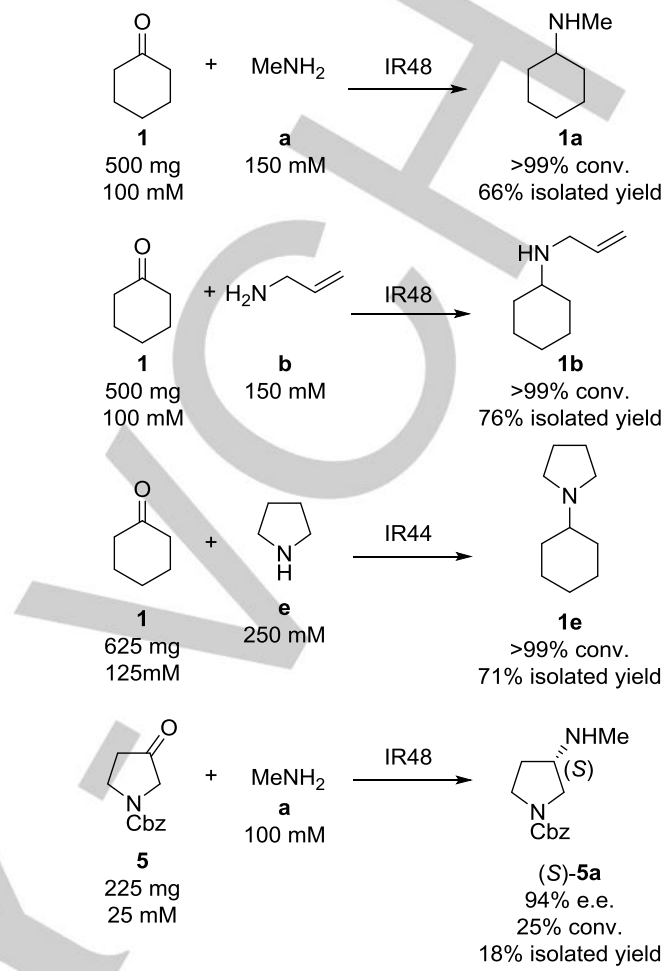

Scheme 1: Preparative-scale reductive amination biotransformations Reaction conditions: Enzyme lysate $(10 \% \mathrm{v} / \mathrm{v})$, glucose $\left(1.1 \mathrm{eq}\right.$ ), $\mathrm{NADP}^{+}(0.5$ $0.6 \mathrm{mg} / \mathrm{mL})$ and $\mathrm{GDH}(\mathrm{CDX} 901,0.5-0.6 \mathrm{mg} / \mathrm{mL})$ in Tris buffer $(100 \mathrm{mM}), 30^{\circ} \mathrm{C}$, $\mathrm{pH} 9,350 \mathrm{rpm}$ for $24 \mathrm{~h}$. Maintained at $\mathrm{pH} 8.0$ with titration with $2 \mathrm{~N} \mathrm{NaOH}$.

The 45 enzymes reported in this study were then ranked based on their conversions in reductive amination reactions across the entire substrate set. For the top performing enzymes, their active-site residues were compared to AspRedAm (Figure 3). Interestingly, several of the best performing enzymes cluster together in the cladogram (see Supporting Information) and based on sequence alignments, show a conserved active site aspartate at the position homologous to D169 in AspRedAm. However, at the homologous positions to AspRedAm's N96, Y177 and Q240, there are different residues with serine, tryptophan and histidine being the most commonly found respectively. Homology models of IR48 from Rhizobium sullae and IR91 from Kribbella flavida DSM 17836 were created and their active sites overlaid with that of AspRedAm (Figure 3a). IR48 is representative of the best performing enzymes that have the conserved residues described above and IR91 is an enzyme that has some significantly different active site residues, yet still facilitates reductive amination. It should be noted that none of the highlighted residues is completely conserved across the three active-site architectures shown. There are also significant differences in residue functional equivalence, for example between the homologous Y177, W179 and L180 in AspRedAm, IR48 and IR91 respectively. This analysis serves to highlight that reductive amination catalysed by these enzymes may occur, mechanistically, in different ways compared to that of the recently discovered fungal RedAms, with different modes of 
binding of substrates. However, further experiments are required to prove whether these enzymes are capable of catalysing imine formation, and thus be confidently classified as RedAms.

a) AspRedAm

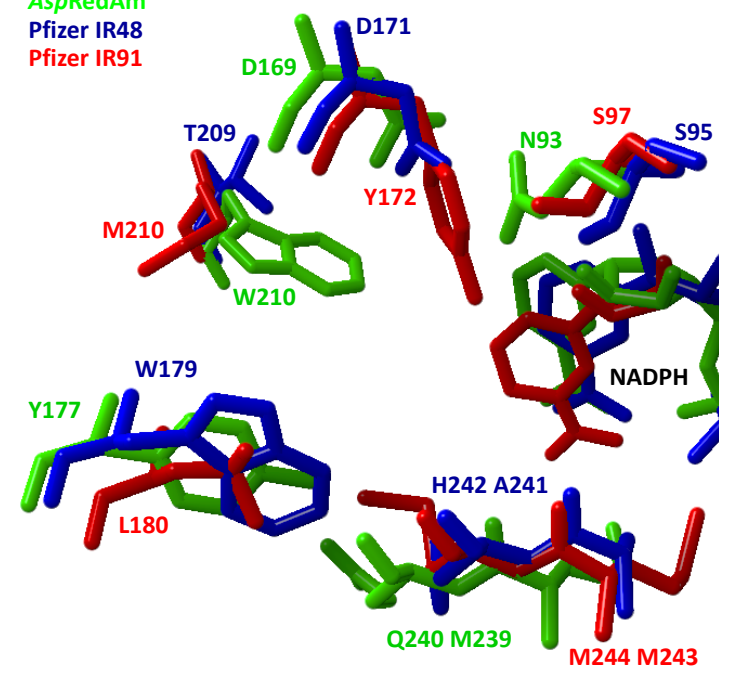

\begin{tabular}{ccccccc}
\hline \multirow{6}{*}{ b) IRED } & N93 & D169 & Y177 & W210 & M239 & Q240 \\
\hline IR48 & S & D & W & W* & A & H \\
IR47 & T & D & W & M & V & H \\
IR50 & S & D & W & W & P & H \\
IR44 & S & D & W & W & A & H \\
IR77 & S & D & W & W & P & H \\
IR56 & S & D & W & W & P & H \\
IR61 & S & D & W & W & P & H \\
IR66 & S & D & W & L & A & H \\
IR91 & S & Y & L & M & M & M \\
IR58 & S & D & W & L & A & H
\end{tabular}

Figure 3: a) Overlay of the active sites of IR48 and IR91 with that of the known reductive aminase AspRedAm. IR48 (blue), IR91 (red), AspRedAm (green). b) Comparison of the active site residues of the best performing enzymes with those of AspRedAm based on identification of homologous residues from sequence alignments. Residues in bold are well conserved. *The result of the structural alignment shown in a) highlights a $T$ in the active site rather than $\mathrm{W}$.

In summary, we have identified a new set of bacterial enzymes capable of performing reductive amination reactions. Several enzymes were found that gave high conversions at low amine equivalents with primary and secondary amines, as well as some with aniline which, until recently, ${ }^{[22]}$ had not been extensively demonstrated as a substrate for reductive aminations with RedAms or IREDs. Preparative-scale biotransformations have shown the potential application of these enzymes, particularly for reactions with near stoichiometric quantities of ketone and amine. If these enzymes indeed catalyse imine formation as well as reduction, then the analysis of active-site residues suggests that this catalysis may be brought about in different ways relative to one another and to the fungal RedAms based on interesting differences in active-site residue functional equivalence. This work broadens the portfolio of IREDs available as the field moves towards the industrial application of biocatalysts for reductive amination.

\section{Acknowledgements}

S.P.F. acknowledges a CASE award from the UK Biotechnology and Biological Sciences Research Council (BBSRC) and Pfizer. J.M.S was funded by grant BB/M006832/1 from the BBSRC and S.L.M. was supported by a CASE studentship from Johnson Matthey. NJT is grateful to the ERC for an Advanced Grant.

\section{Experimental Section}

See supporting information.

Keywords: biocatalysis $\cdot$ imine reductase $\cdot$ reductive amination - amines $\cdot$ chirality

\section{References}

[1] V. N. Wakchaure, J. Zhou, S. Hoffmann, B. List, Angew. Chem. Int. Ed. 2010, 49, 4612-4614.

[2] S. Zhou, S. Fleischer, H. Jiao, K. Junge, M. Beller, Adv. Synth. Catal. 2014, 356, 3451-3455.

[3] K. Kim, C. Lee, C. Cheon, J. Org. Chem. 2015, 80, 63676374.

[4] H. Huang, X. Liu, L. Zhou, M. Chang, X. Zhang, Angew. Chem. Int. Ed. 2016, 55, 5309-5312.

[5] H. Huang, Y. Zhao, Y. Yang, L. Zhou, M. Chang, Org. Lett. 2017, 19, 1942-1945.

[6] C. Wang, J. Xiao, Top. Curr. Chem. 2014, 261-282.

[7] H. Blaser, H. Buser, H. Jalett, F. Spindler, Synlett 1999 867-868.

[8] C. J. Cobley, J. P. Henschke, Adv. Synth. Catal. 2003, 345, 195-201.

[9] S. Zhu, J. Xie, Y. Zhang, S. Li, Q. Zhou, J. Am. Chem. Soc. 2006, 128, 12886-12891.

[10] A. Trifonova, J. S. Diesen, P. G. Andersson, Chem. Eur. J. 2006, 12, 2318-2328.

[11] H.-U. Blaser, R. Hanreich, H.-D. Schneider, F. Spindler, B. Steinacher, (Eds. H.-U. Blaser, E. Schmidt), Wiley-VCH, Weinheim, 2004, 55-70.

[12] G. Hou, F. Gosselin, W. Li, C. McWilliams, Y. Sun, M. Weisel, P. D. O'Shea, C. Chen, I. W. Davies, X. Zhang, J. Am. Chem. Soc. 2009, 131, 9882-9883.

[13] J. Mangas-Sanchez, S. P. France, S. L. Montgomery, G. A. Aleku, H. Man, M. Sharma, J. I. Ramsden, G. Grogan, N. J. Turner, Curr. Opin. Chem. Biol. 2017, 37, 19-25.

[14] G. Grogan, N. J. Turner, Chem. Eur. J. 2016, 22, 19001907.

[15] J. H. Schrittwieser, S. Velikogne, W. Kroutil, Adv. Synth. Catal. 2015, DOI 10.1002/adsc.201500420.

[16] F. Leipold, S. Hussain, S. P. France, N. J. Turner, in Sci. Synth. Biocatal. Org. Synth. 2 (Eds.: K. Faber, W. Fessner, N.J. Turner), Georg Thieme Verlag, Stuttgart, 2015, pp. 359-382.

[17] D. Wetzl, M. Gand, A. Ross, H. Müller, P. Matzel, S. P. Hanlon, M. Müller, B. Wirz, M. Höhne, H. Iding, ChemCatChem 2016, 8, 2023-2026.

[18] P. Matzel, M. Gand, M. Höhne, Green Chem. 2017, 19, 385-389.

[19] P. N. Scheller, M. Lenz, S. C. Hammer, B. Hauer, B. M. Nestl, ChemCatChem 2015, 7, 3239-3242.

[20] T. Huber, L. Schneider, A. Präg, S. Gerhardt, O. Einsle, M. Müller, ChemCatChem 2014, 6, 2248-2252.

[21] Z. Maugeri, D. Rother, J. Biotechnol. 2017, 258, 167-170.

[22] G.-D. Roiban, M. Kern, Z. Liu, J. Hyslop, P. Lyn Tey, M. S. Levine, L. S. Jordan, K. Brown, T. Hadi, L. A. F. Ihnken, et al., ChemCatChem 2017, DOI: 10.1002/cctc.201701379.

[23] G. A. Aleku, S. P. France, H. Man, J. Mangas-Sanchez, S. L. Montgomery, M. Sharma, F. Leipold, S. Hussain, G. Grogan, N. J. Turner, Nat. Chem. 2017, DOI:10.1038/nchem.2782. 
[24] M. J. Abrahamson, E. Vazquez-Figueroa, N. B. Woodall, J. C. Moore, A. S. Bommarius, Angew. Chem. Int. Ed. 2012, 51, 3969-3972.

[25] L. J. Ye, H. H. Toh, Y. Yang, J. P. Adams, R. Snajdrova, Z. Li, ACS Catal. 2015, 5, 1119-1122.

[26] H. Mihara, H. Muramatsu, R. Kakutani, M. Yasuda, M. Ueda, T. Kurihara, N. Esaki, FEBS J. 2005, 272, 11171123.

[27] M. Sharma, J. Mangas-Sanchez, N. J. Turner, G. Grogan, Adv. Synth. Catal. 2017, DOI: 10.1002/adsc.201700356.

[28] H. Chen, J. Moore, S. J. Collier, D. Smith, J. Nazor, G. Hughes, J. Janey, G. Huisman, S. Novick, N. Agard, et al., Engineered Imine Reductases and Methods for the Reductive Amination of Ketone and Amine Compounds., 2013.

[29] H. Man, E. Wells, S. Hussain, F. Leipold, S. Hart, J. P. Turkenburg, N. J. Turner, G. Grogan, ChemBioChem 2015, 16, 1052-1059.

[30] M. Gand, H. Müller, R. Wardenga, M. Höhne, J. Mol. Catal. B Enzym. 2014, 110, 126-132.

[31] K. Mitsukura, M. Suzuki, S. Shinoda, T. Kuramoto, T. Yoshida, T. Nagasawa, Biosci. Biotechnol. Biochem. 2011, 75, 1778-1782.

[32] S. Hussain, F. Leipold, H. Man, E. Wells, S. P. France, K. R. Mulholland, G. Grogan, N. J. Turner, ChemCatChem 2015, 7, 579-583.

[33] K. Mitsukura, T. Kuramoto, T. Yoshida, N. Kimoto, H. Yamamoto, T. Nagasawa, Appl. Microbiol. Biotechnol. 2013, 97, 8079-8086.

[34] F. Leipold, S. Hussain, D. Ghislieri, N. J. Turner, ChemCatChem 2013, 5, 3505-3508.

[35] M. Rodriguez-Mata, A. Frank, E. Wells, F. Leipold, N. J. Turner, S. Hart, J. P. Turkenburg, G. Grogan, ChemBioChem 2013, 14, 1372-1379.

[36] S. P. Meduna, B. M. Savall, H. Cai, J. P. Edwards, R. L. Thurmond, P. M. Mcgovern, Bioorg. Med. Chem. Lett. 2011, 21, 3113-3116.

[37] H. Cai, F. Chavez, P. J. Dunford, A. J. Greenspan, S. P. Meduna, J. A. Quiroz, B. M. Savall, K. L. Tays, R. L.

Thurmond, J. Wei, et al., Diamino-Pyridine, Pyrimidine, and Pyridazine Modulators of the Histamine H4 Receptor, 2009, WO2009152325 (A1).

[38] S. Allen, W. C. Blackwell lii, E. Boros, J. L. Collins, D. Hertzog, X. Liang, J. Ray, S. M. Reister, V. Samano, R. Sherrill, Bis-Pyridylpyridones as Melanin-Concentrating Hormone Receptor 1 Antagonists, 2009, WO2009076387 (A1).

[39] P. Devasthale, W. N. Washburn, W. Wang, A. Hernandez, S. Ahmad, G. Zhao, Azolopyrrolone Melanin Concentrating Hormone Receptor-1 Antagonists, 2010, WO2010047956 (A1).
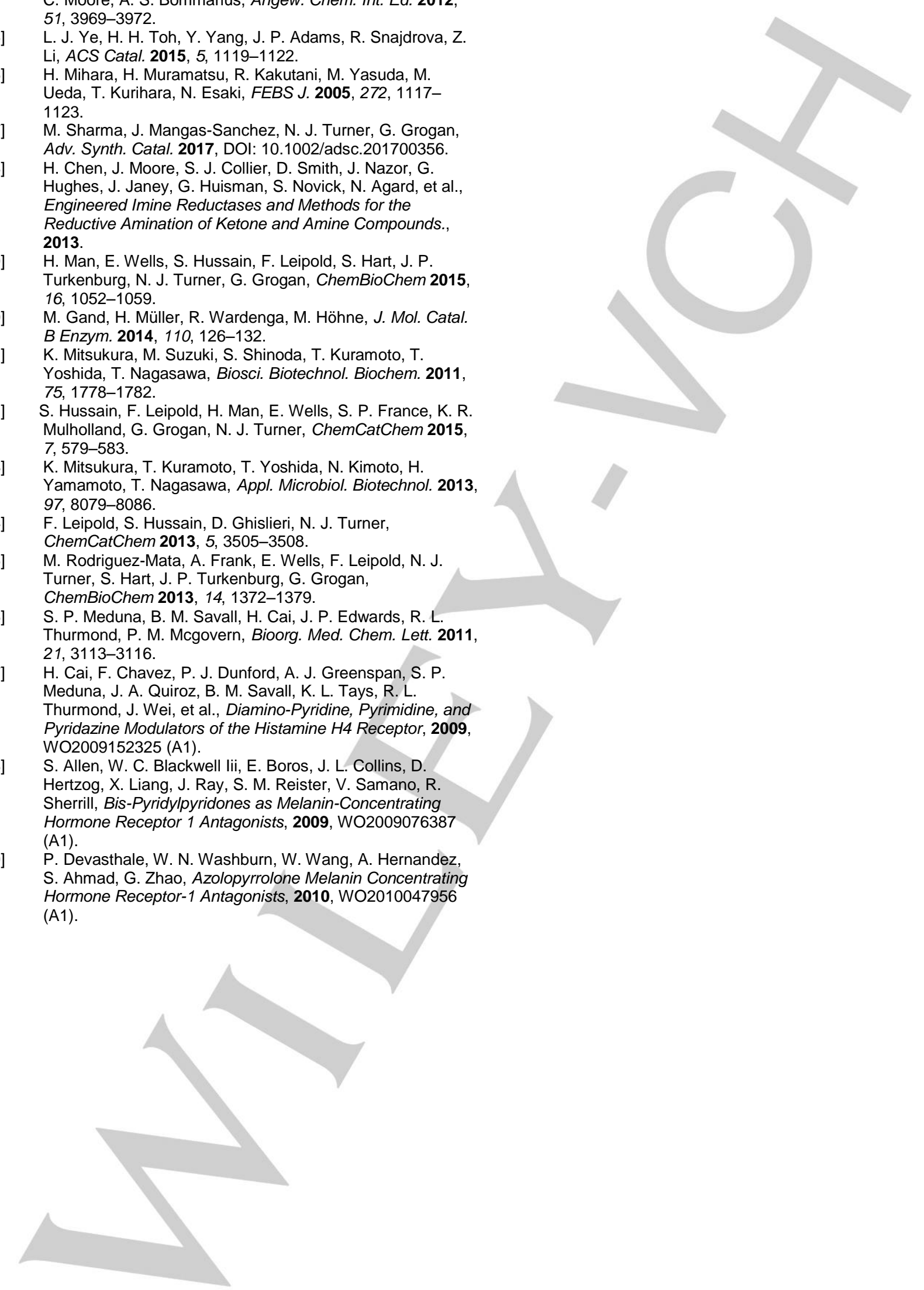
Layout 1:

\section{COMMUNICATION}

A diverse group of novel imine reductases (IREDs) were expressed and screened as cell-free lysates for their ability to facilitate reductive amination. A range of ketones and amines were examined and enzymes identified that accepted benzylamine, pyrrolidine, ammonia and aniline. Amine equivalents as low as 2.5 afforded up to $>99 \%$ conversion and up to $>98 \%$ e.e. Preparative-scale reactions with low amine equivalents (1.5 or 2.0) of methylamine, allylamine and pyrrolidine, achieved up to $>99 \%$ conversion and $76 \%$ isolated yield.
Scott P. France, Roger M. Howard, Jeremy Steflik, Nicholas J. Weise, Juan Mangas-Sanchez, Sarah L. Montgomery, Robert Crook, Rajesh Kumar $^{\star}$ and Nicholas J. Turner

Page No. - Page No.

Identification of Novel Bacterial Members of the Imine Reductase Enzyme Family that Perform Reductive Amination 